\title{
On the history of the Department of Invertebrate Zoology, Moscow State University
}

\begin{abstract}
V.V. Malakhov
Department of Invertebrate Zoology, Lomonosov Moscow State University, Leninskie gory 1-12, Moscow119991 Russia.E-mail:vmalakhov@inbox.ru

ABSTRACT: This brief article describes the history of the Department of Invertebrate Zoology at Moscow University. The article covers the period from 1858 to the beginning of the 21 st century.

How to cite this article: Malakhov V.V. 2019. On the history of the Department of Invertebrate Zoology, Moscow State University // Invert. Zool. Vol.16. No.1. P.6-18. doi: 10.15298/invertzool.16.1.02
\end{abstract}

KEY WORDS: Invertebrate Zoology, Moscow University, history of science.

\section{Об истории кафедры зоологии беспозвоночных Московского государственного университета}

\begin{abstract}
В.В. Малахов
Кафедра зоологии беспозвоночных, Биологический факультет, Московский государственный университет имени М.В. Ломоносова, Ленинские горы 1-12, Москва 119991 Россия. E-mail:vmalakhov@inbox.ru

РЕЗЮМЕ: Статья представляет собой краткий очерк истории кафедры зоологии беспозвоночных Московского государственного университета. Статья охватывает период с 1858 г. до начала 21-го века.

Как цитировать эту статью: Malakhov V.V. 2019. On the history of the Department of Invertebrate Zoology, Moscow State University // Invert. Zool. Vol.16. No.1. P.6-18. doi: 10.15298/invertzool. 16.1.02
\end{abstract}

КЛЮЧЕВЫЕ СЛОВА: Зоология беспозвоночных, Московский государственный университет, история науки.

In recent years, new faculties and departments have frequently appeared at Moscow University. This has allowed Moscow University to keep pace with the times. However, the old faculties and departments are the keepers of the traditions of Russian scientific and educational schools. One of them is the Department of Invertebrate Zoology. In 1842, Professor Charles Roulier (Fig. 1), an outstanding scien- tist-encyclopedist, began to read a course of lectures on Invertebrate Zoology for the first time. He was an original thinker and came up with the idea of evolution independent of Charles Darwin. At that time, the idea of evolution was regarded as heretical and was met with hostility from some figures in the Russian Orthodox Church. As a consequence, Professor Roulier was under the supervision of the Tsar's secret 


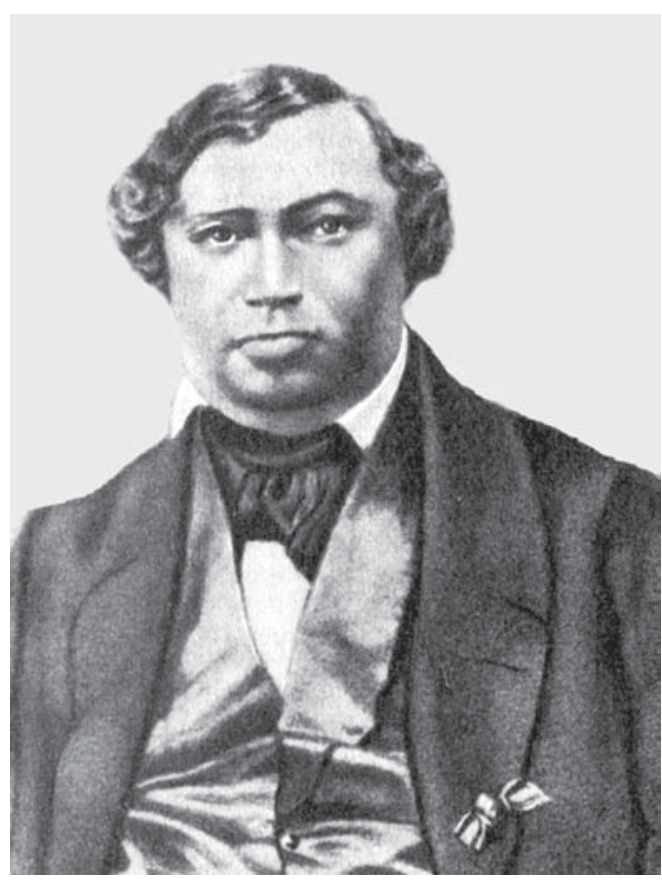

Fig. 1. Professor Charles Roulier (1814-1858).

Рис. 1. Профессор Карл Францевич Рулье (18141858).

police. Charles Roulier promoted the idea of acclimatization of new species of animals in order to use them in agriculture.

In 1858, one of the disciples and followers ofCharles Roulier, Professor Anatoly Bogdanov, took the position of Director of the Zoological Museum of Moscow University, where the Division of Invertebrate Zoology was established. That is why 1858 may be considered as the founding year of the Department of Invertebrate Zoology at Moscow University. A corresponding member of the Imperial St. Petersburg Academy of Sciences, Professor Anatoly Bogdanov (Fig. 2) studied animal systematics and geography, parasitology, anthropology, and acclimatization of animals. In 1864 on Bogdanov's initiative, the Moscow Zoo was founded. It was the first zoo in Russia.

Anatoly Bogdanov's special concern was the development of Russian biological stations. In 1891, one of his closest collaborators, Nikolay Zograf, organized the biological station

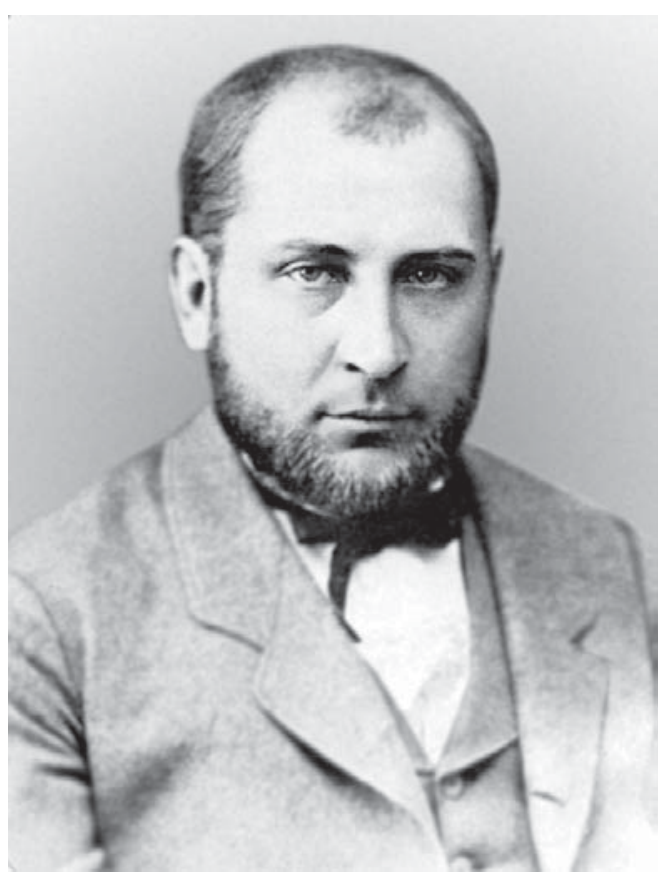

Fig. 2. Professor Anatoly Bogdanov (1834-1896). Рис. 2. Профессор Анатолий Петрович Богданов (1834-1896).

"Glubokoe Ozero" near Moscow. It is the oldest biological station in Russia, and it still exists. Anatoly Bogdanov was an outstanding teacher. Disciples and followers of Anatoly Bogdanov included many famous Russian professors and academicians, such as D.N. Anuchin, L.S. Berg, S.S. Chetverikov, A.A. Korotneff, G.A. Kozhevnikov, N.M. Kulagin, N.V. Nasonov, V.M. Schimkevitch, S.A. Zernov, and N.Yu. Zograf.

Anatoly Bogdanov died in 1896 and was succeeded by Professor Alexander Tikhomirov (Fig. 3). Professor Tikhomirov studied the development of hydroid polyps, crustaceans, and insects. The most famous scientific achievement of Alexander Tikhomirov was the discovery of parthenogenesis in silkworms. Tikhomirov found that parthenogenesis can be induced by temperature shock and the action of acids. A few decades later, this phenomenon was introduced into the practice of commercial sericulture by the academician B.L. Astaurov. Alexander 


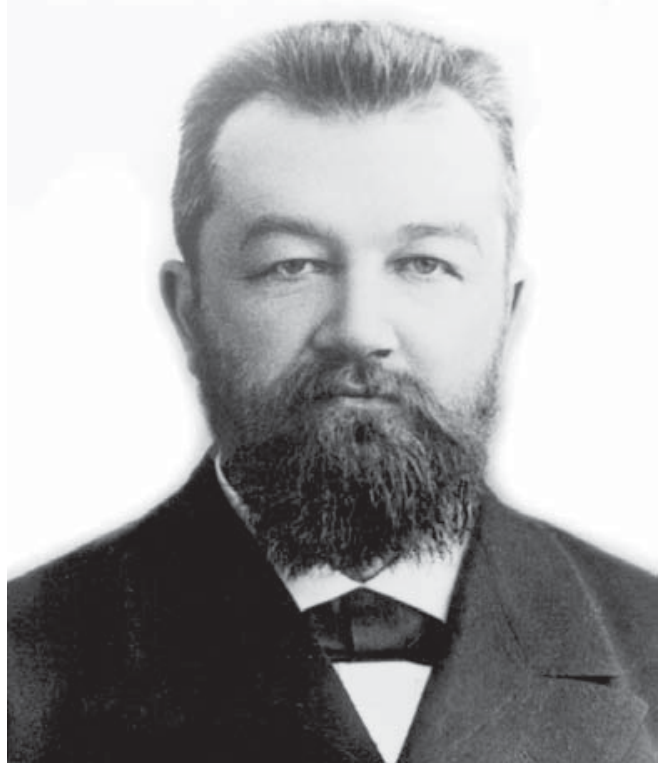

Fig. 3. Professor Alexander Tikhomirov (18501931).

Рис. 3. Профессор Александр Андреевич Тихомиров (1850-1931).

Tikhomirov was known for his struggle against Darwinism and the theory of evolution, which greatly contributed to his career. He took the position of rector of Moscow University, and then stood at the head of the Moscow school district. As rector, Tikhomirov completed the construction of a hostel for students and a new building of the Zoological Museum, and contributed to the opening of new institutes and departments. After 1917, however, Tikhomirov lost all his positions and lived in extreme poverty in Sergiev Posad.

Professor Grigory Kozhevnikov (Fig. 4) became a Director of the Zoological Museum of Moscow University in 1904. He studied domestic bees and other social insects, and initiated research into the biology of malaria-transmitting mosquitoes and their role in malaria epidemiology. He was the first to study the cave fauna of Russia. Professor Kozhevnikov believed that it was necessary to begin studying the unique fauna of lake Baikal. Several young members of the Department (L.A. Zenkevitch, L.L. Rossolimo, I.I. Mesyatsev, G.G. Abrikosov, V.V. Al-

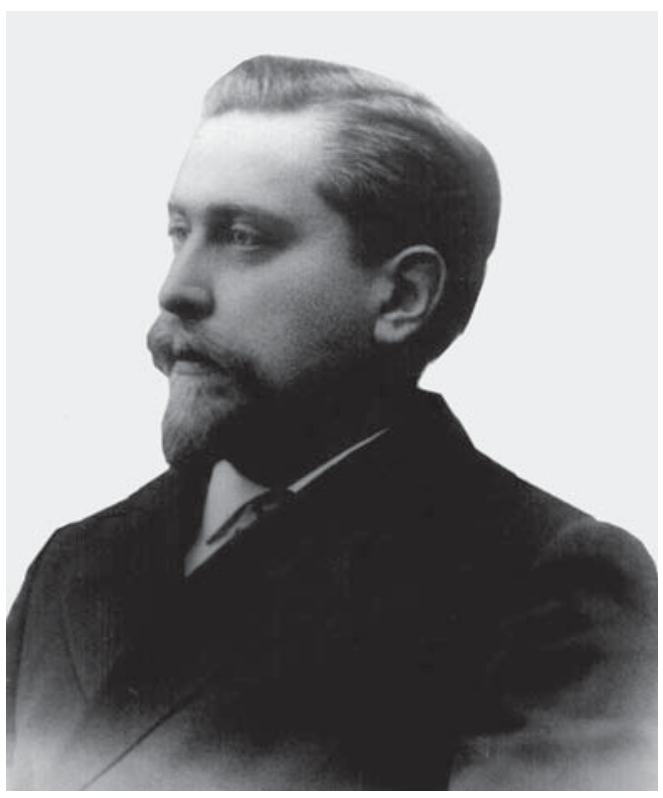

Fig. 4. Professor Grigory Kozhevnikov (18661933).

Рис. 4. Профессор Григорий Александрович Кожевников (1866-1933).

patov, and A.D. Starostin) went to lake Baikal in 1917. After the October revolution, the civil war began, and these scientists could not return to Moscow for several years. Grigory Kozhevnikov fought for the creation of nature reserves in Russia. In his office, he hung a poster with a Latin aphorism "Primo nosce patriam, postea viator eris" (First your motherland, then travel).

As Director of the Zoological Museum, Kozhevnikov survived three Russian revolutions, World War I, the Russian civil war, military communism, the New Economic Policy, and all other twists and turns of Russian history in the first decades of the 20th century. Grigory Kozhevnikov sometimes looked like a typical absent-minded and eccentric professor. If somewhere a painting fell from the wall, it definitely fell on the Professor Kozhevnikov's head. Walking down the street, the Professor could have fallen through the water-conduit well. People of this kind usually have a strong guardian angel.

One day a guardian angel saved the Professor. In the early 1920s, inflation soared rapidly. Every week, the Zoological Museum had to 


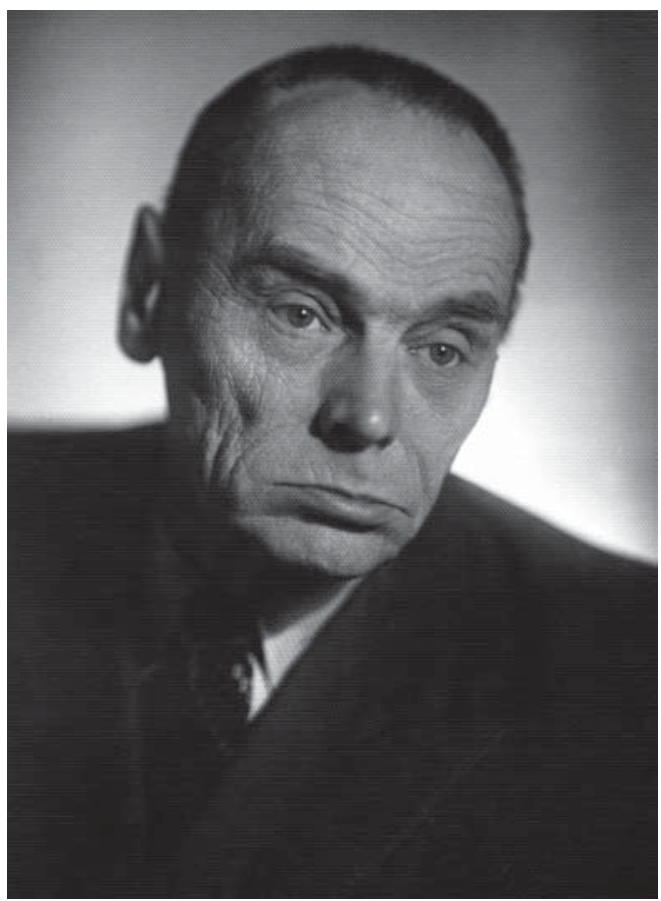

Fig. 5. Nikolay Plavilschikov (1892-1962).

Рис. 5. Николай Николаевич Плавильщиков (1892-1962).

send an armed young employee to the bank for money. Once, a young entomologist, Nikolay Plavil'shikov, was sent for money. He brought the money to the Professor's apartment. When the Professor began to count the money, the entomologist shot him twice in the forehead with a Smith and Wesson revolver. Plavil'shikov did not take the money. Later, when he was interrogated, he could not explain his behavior. What happened to the Professor? He did not die, and after being unconscious for half an hour, he came to. The bullets from the revolver didn't penetrate the Professor's forehead. When Plavil'shikov was tried, his lawyer said: "There are one million species of insects, and Plavil'shikov knows the Latin names of all these insects. How can such a person be quite healthy mentally?" Plavil'shikov was declared insane. Later, Plavil'shikov returned to the Zoological Museum, worked there for the rest of his life, became a famous entomologist, and wrote many books (Fig. 5).

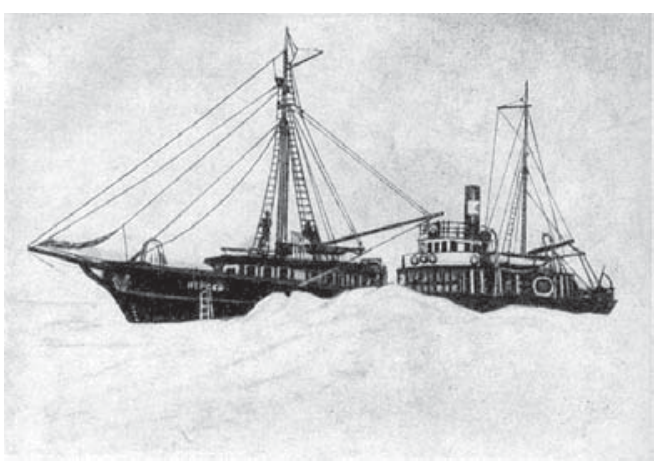

Fig. 6. "Perseus" in the ice of the Barents Sea. Рис. 6. «Персей» во льдах Баренцева моря.

In 1929, Professor Grigory Kozhevnikov, now an old professor, was dismissed as the Director of the Zoological Museum, and was replaced by the famous hydrobiologist, Professor Ivan Mesyatsev, who was an active member of the Communist party. In 1921, with the support of the Soviet leader V.I. Lenin, Professor Mesyatsev organized a Floating Marine Scientific Institute (PLAVMORIN). In 1923, the first Soviet expedition ship, "Perseus", was launched. In the period from 1921 to 1927 , Professor Mesyatsev headed several expeditions to the northern seas of the USSR, and was accompanied by L.A. Zenkevich and V.A. Brotskaya, V.G. Bogorov, N.N. Zubov, M.V. Klenova, S.V. Obruchev, T.S. Rass, A.A. Shorygin, V. Shuleikin, V.A. Yashnov, and other scientists who would become famous Russian oceanographers. The wooden "Perseus" reached $81^{\circ} \mathrm{N}$, where even icebreakers had not previously penetrated (Fig. 6). Since that time, marine biology has been the focus of the Department's research.

The official title "Department of Zoology and Comparative Anatomy of Invertebrates" appeared in 1930, and its first head was Professor Lev Zenkevitch. Professor Zenkevitch headed the Department from 1930 to 1970 (Fig. 7). Marine biology continued to be the main direction of the scientific work of the Department. Professor Zenkevitch developed the doctrine of the biological structure of the World Ocean, and he paid much attention to the study of deep-sea fauna, marine biocenology, biogeography, ac- 


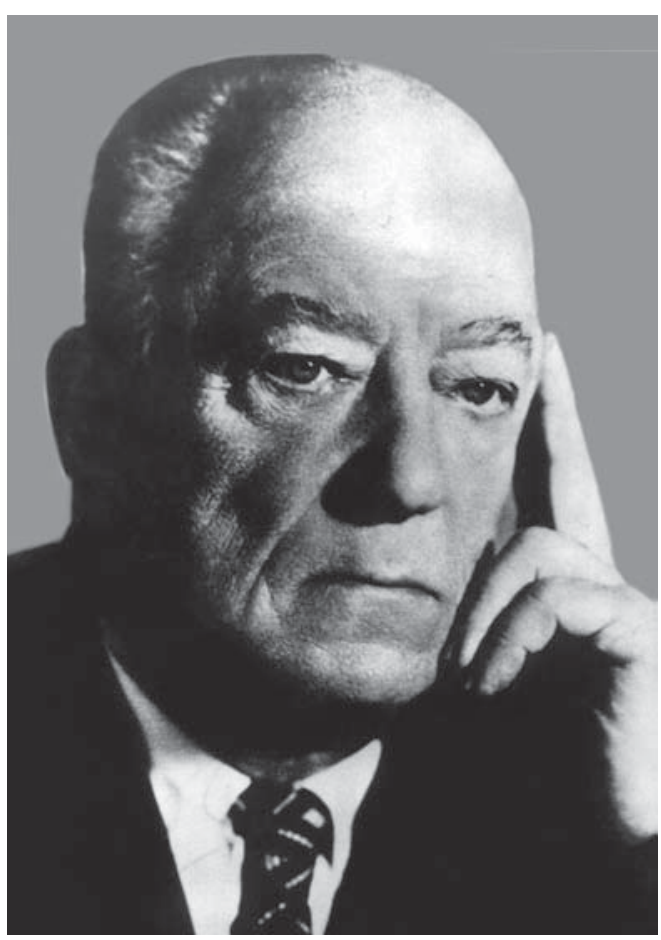

Fig. 7. Professor Lev Zenkevitch (1889-1970).

Рис.7. Профессор Лев Николаевич Зенкевич (1889-1970).

climatization of marine organisms, and other issues of marine biology.

What about old Professor Kozhevnikov, who was shot twice in the forehead? For the rest of his life, Grigory Kozhevnikov taught the course for beekeepers. Before his death in 1933, Grigory Kozhevnikov had bequeathed his brain to Professor B. Gindze, who studied brain structure. Professor Gindze's post-mortem examination revealed that the bones of Grigory Kozhevnikov's skull were extraordinarily thick. That's apparently why the bullets from Plavil'shikov's revolver did not penetrate the old Professor's forehead.

In the 1930 s to $40 \mathrm{~s}$, one of the directions of the scientific work of the Department concerned a practical focus on the acclimatization of invertebrates. This research was inspired by the ideas of Charles Roulier and Anatoly Bogdanov. The goal of the research was to enrich the fauna of the Caspian Sea with invertebrates from the
Black Sea in order to increase the food resources of sturgeons and other fish. The introduction of new species is an extremely risky undertaking. Very careful environmental studies are needed to ensure that the introduction does not cause harm. Almost all members of the Department, including staff and students, participated in these studies. The well-known result was the introduction of the polychaete worm Nereis diversicolor and the bivalve mollusk Abra (Syndesmia) ovata to the Caspian Sea. Currently, both species are abundant in the Caspian Sea, where they are readily consumed by fish. This is one of the unique examples of successful introduction.

Professor Zenkevitch believed that Moscow University should have a marine biological station. In 1939, the White Sea Biological Station of Moscow University was founded. Unfortunately, development of the White Sea Biological Station was prevented by World War II. The subsequent development of the White Sea Biological Station is closely connected with $\mathrm{Ni}$ kolay Pertsov, a graduate of the Department of Invertebrate Zoology. He belonged to the generation that passed through the World War II, which for the Russian people became the Great Patriotic war. After graduating from school in 1941, Nikolay Pertsov went to the front as a volunteer to defend Moscow from Nazi troops. After the war, he graduated from Moscow University. In 1951, he came to the shores of the White Sea. At the site of the future biological station, there were neither laboratories nor living quarters. Only two or three dilapidated log sheds were on the lonely shore of the cold White Sea. Pertsov had to start all over again.

Nikolay Pertsov was the Director of the Biological Station from 1951 until his death in 1987 (Fig. 8). Even though he lacked the necessary funds, Nikolay Pertsov was able to build laboratories and houses, and provided the station with scientific equipment and research vessels (Fig. 9). From year to year, hundreds of students worked at the station as volunteers. Under the leadership of Nikolay Pertsov, they built laboratories and living houses. They built a power line that crossed the taiga. As a result of Nikolai Pertsov's activities, a scientific town in 


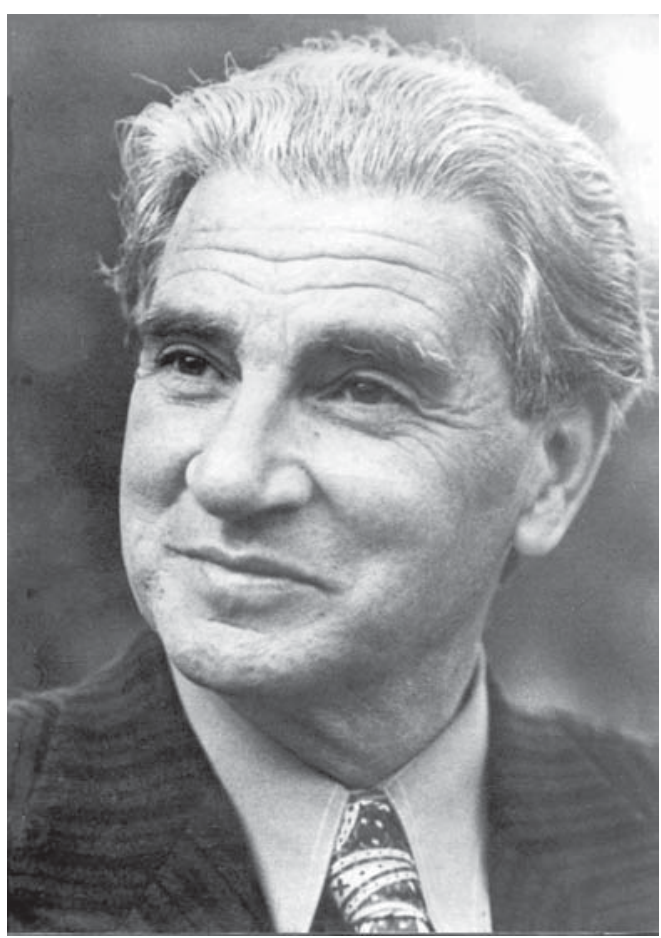

Fig. 8. Nikolay Pertsov (1924-1987).

Рис. 8. Николай Андреевич Перцов (1924-1987).

which several hundred people could live and study appeared in the taiga.

The White Sea Biological Station is now a world-famous center of science and education in the north of Russia. Hundreds of students and researchers from Russia and other countries come to the White Sea Biological Station every year (Fig. 10). The White Sea Biological Station remains closely connected with the Department of Invertebrate Zoology. The current director of the White Sea Biological Station is Alexander Tzetlin, who is a professor in the Department of Invertebrate Zoology.

In the 1930s, a 19-year-old student named George Gause began his research in the Department of Invertebrate Zoology (Fig. 11). George Gause was born in 1910 in Moscow; his father was Frants Gause, a professor of architecture. As a young man, Gause took summer vacations in the Caucasus Mountains. It was during these trips to the Caucasus Mountains that Gause grew fond of nature. His university advisor was the zoologist Vladimir Alpatov, who headed the Laboratory of Ecology and Useful Invertebrates at the Department of Invertebrate Zoology. In the mid-1920s, Vladimir Alpatov visited the laboratory of Raymond Pearl, a well-known biologist and demographer at Johns Hopkins University in Baltimore (USA). Vladimir Alpatov returned to Russia with a fascination for American science that was very influential on Gause. Gause contacted Pearl to see whether the American would take on another Russian student, but his application was denied. If his

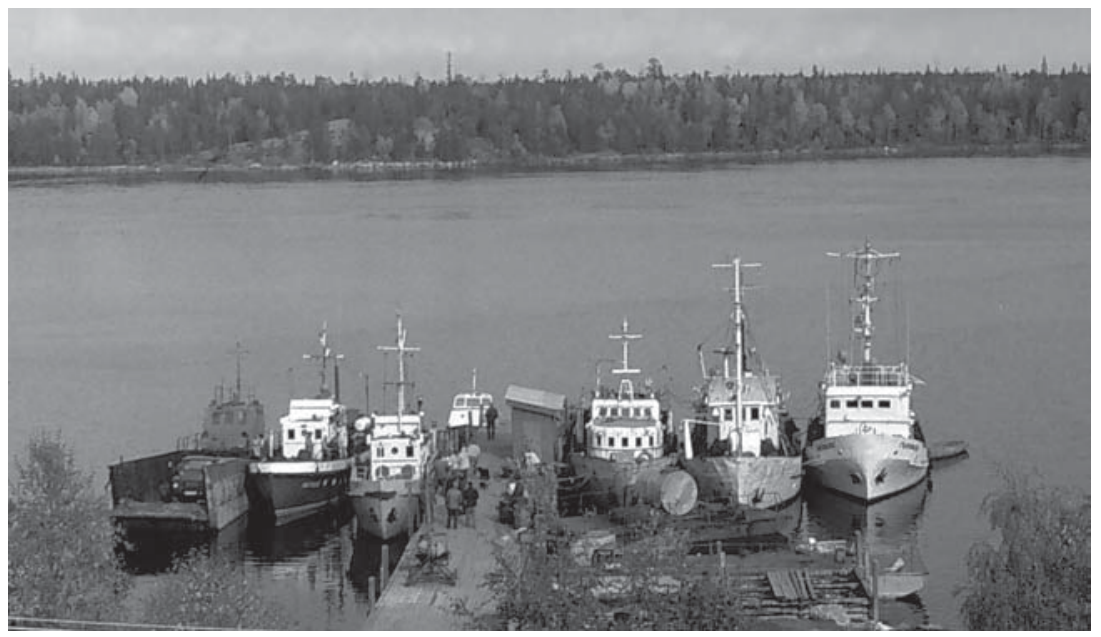

Fig. 9. The White Sea Biological Station fleet in 1976.

Рис. 9. Флот Беломорской биологической станции МГУ в 1976 г. 


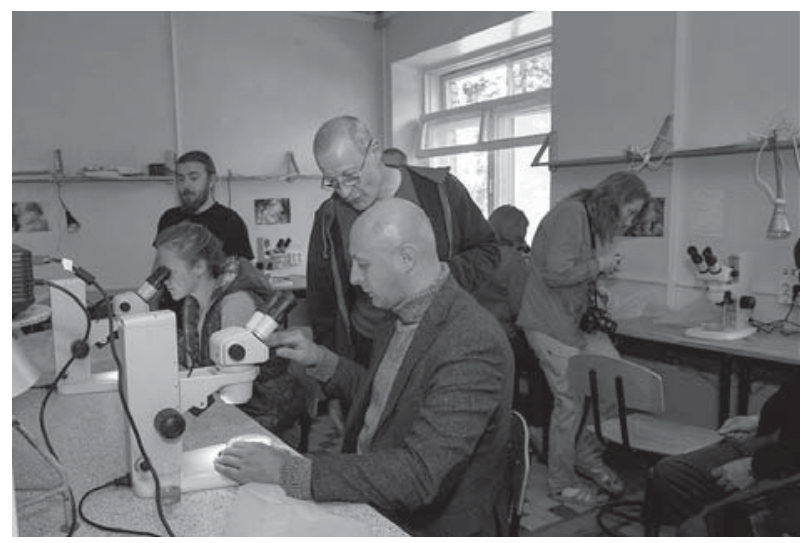

Fig. 10. Professor Alexander Tzetlin (stands in the center) in one of the laboratories of the White Sea Biological Station in 2012. Рис. 10. Профессор А.Б. Цетлин (стоит в центре) в одной из лабораторий Беломорской биологической станции в 2012 г.

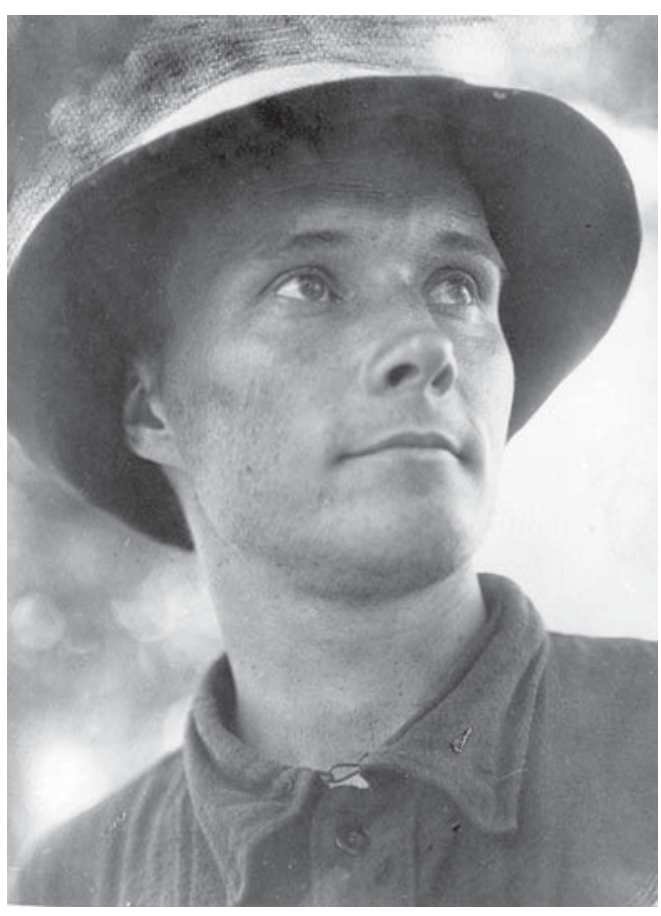

Fig. 11. George Gause (1910-1986).

Рис. 11. Георгий Францевич Гаузе (1910-1986).

icidin to Great Britain, an ally in the anti-Hitler coalition. The young British chemist Margaret Roberts (future British Prime Minister Margaret Thatcher) was involved in the study of new antibiotics designed by George Gause (Fig. 12). request had been granted, Russia would have lost a brilliant researcher.

In 1932, George Gause published an article entitled "Experimental studies on the struggle for existence" in the Journal of Experimental Biology. In this paper, he formulated what has become to be known as the "competitive exclusion principle" or "Gause's law". The publication was based on experimental work done with mixed cultures of yeast and two Paramecium species. The principle asserts that no two species with similar ecological niches can coexist in a stable equilibrium. The fate of the less efficient species is local extinction. This publication brought Gause worldwide fame as one of the founders of ecology. It is worth emphasizing that at this time George Gause was only 22 years old.

George Gause and his wife Maria Brazhnikova, who was also a scientist, then focused their research on practical applications of the new principle. They noticed that the growth of Staphylococcus aureus was inhibited in mixed cultures with a strain of Bacillus brevis. The inhibition of $S$. aureus was caused by a metabolite produced by B. brevis. George Gause isolated this antibiotic and named it 'Gramicidin'. The antibiotic went into mass production during the Great Patriotic War and saved many lives. In 1944, the USSR handed over the secret of gram- 


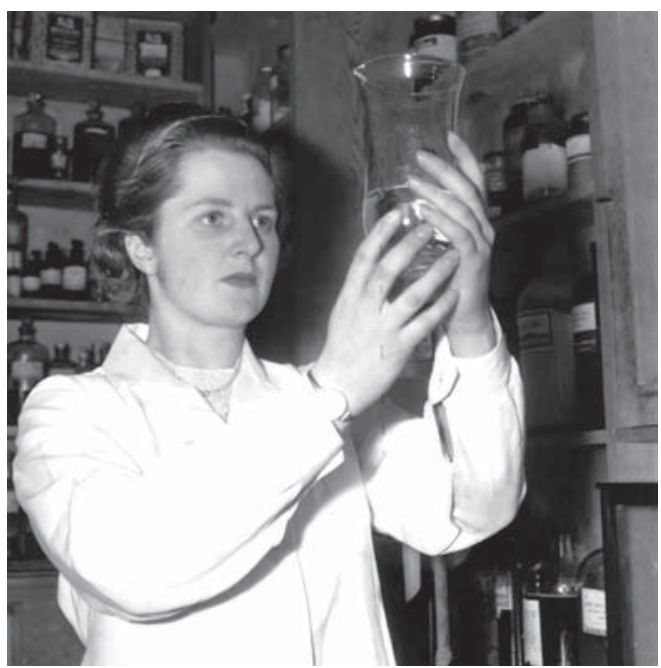

Fig. 12. The young British chemist Margaret Roberts (future British Prime Minister Margaret Thatcher) studies the new antibiotic designed by Russian zoologist George Gause.

Рис. 12. Молодой британский химик Маргарет Робертс (будущий премьер-министр Великобритании) исследует новый антибиотик, созданный российским зоологом Георгием Гаузе.

In 1946, George Gause and Maria Brazhnikova were awarded the Stalin Prize. George Gause took the position of Director of the Institute for New Antibiotics in Moscow. As director, Gause helped to design and manufacture many novel antibiotics, a few of which had anti-tumor capacities.

At the very beginning of the Great Patriotic War, many employees and students of the Department went to the front, and many remained on the battlefield forever. Among those who heroically died at the front were senior researcher Nikolay M. Kinalev and students Oleg A. Lipin, George A. Permyakov, and Oleg N. Radchenko. We will never forget their names! Assistant Professor Kirill A. Voskresensky, senior researcher Boris M. Logvinenko, Professor Peter V. Matekin, director of the White Sea Biological Station Nikolay A. Pertsov, and Professor Vladimir A. Sveshnikov fought bravely at the fronts, and after the war worked in the Department to the 1980 s.

In the midst of the war in 1944, Professor

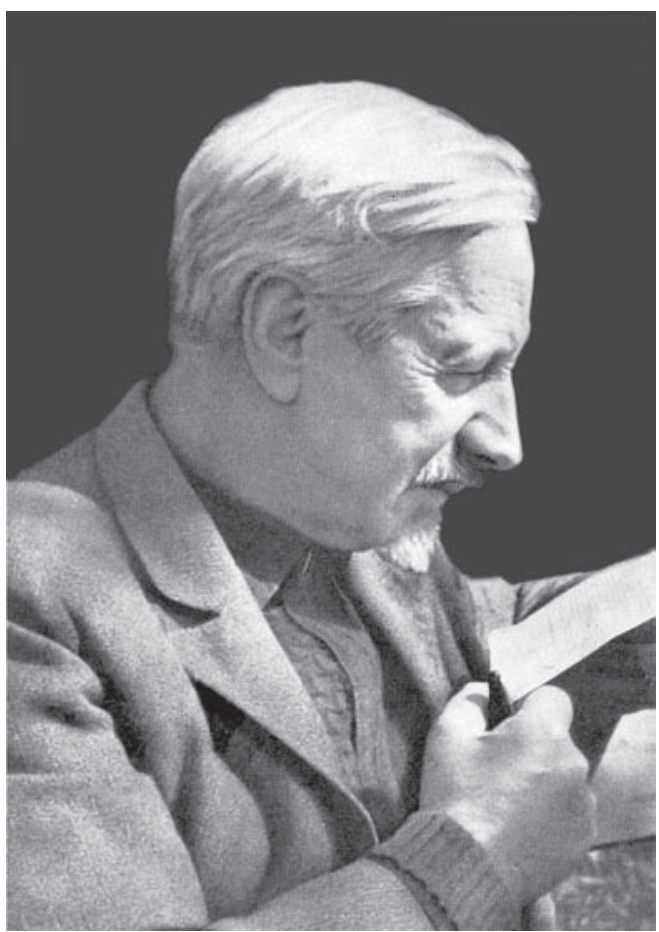

Fig. 13. Vladimir Beklemishev (1890-1962).

Рис. 13. Профессор Владимир Николаевич Беклемишев (1890-1962).

Vladimir N. Beklemishev (Fig. 13) published the book "Fundamentals of Comparative Anatomy of Invertebrates". This book was awarded the Stalin prize. The book was reissued three times in the Soviet Union and was also published in English, German, Polish, and other languages. For many years, Professor Beklemishev lectured on the comparative anatomy of invertebrates for students of the Department of Invertebrate Zoology.

After the war, the Soviet Union received the German hospital vessel "Mars" as a part of reparations. It was converted into a marine research vessel named the "Vityaz" (Fig. 14). The "Vityaz" made 65 research cruises in the Pacific, Indian, and Atlantic oceans, passing a total of 800 thousand nautical miles and conducting research at 7943 locations. The head of the Department of Invertebrate Zoology, Professor Lev Zenkevitch, at the same time headed the Laboratory of the Benthos at the P.P. Shir- 


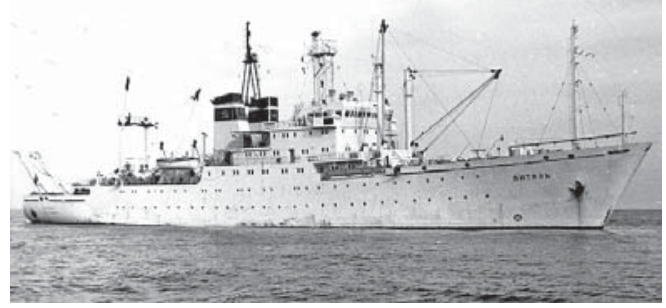

Fig. 14. Soviet research ship "Vityaz".

Рис. 14. Советское исследовательское судно «Витязь».

shov Institute of Oceanology. He participated in many expeditions on the "Vityaz" and other Soviet research vessels. Zenkevitch's classic works ("Fauna and biological productivity of the sea", "The Seas of the USSR, their fauna and flora", "Biology of the seas of the USSR", etc.) have been translated into English, Polish, and Japanese, and are widely known all over the world. Professor Zenkevitch was awarded the Stalin prize in 1951 and the Lenin prize in 1965. The French Oceanographic Institute awarded him the gold medal of Prince Albert of Monaco. In 1968, Professor Zenkevitch was elected a full member of the USSR Academy of Sciences.

There were always many everyday problems at the Department. Associate Professors George Abrikosov (Fig. 15) and Vera Brotskaya (Fig. 16) were faithful assistants to Zenkevich. They organized teaching and solved numerous practical problems. Students liked their teachers. They affectionately called the strict Abrikosov "Gor Gorych" (It sounds like the name of the character "Gorynych" in a famous Russian fairy tale). Associate Professor Brodskaya had the nickname "mama Vera" (which means "the mom Vera").

In 1948, after the infamous session of the All-Union Academy of Agricultural Sciences (VASKhNIL), the dictatorship of the academician Trofim Lysenko was established in Soviet biology. These events greatly affected the Biological Faculty of Moscow University. Many departments were destroyed. Many famous professors lost their jobs. Their places were taken by impostors, but Professor Zenkevitch was able to protect his Department. In 1955, he

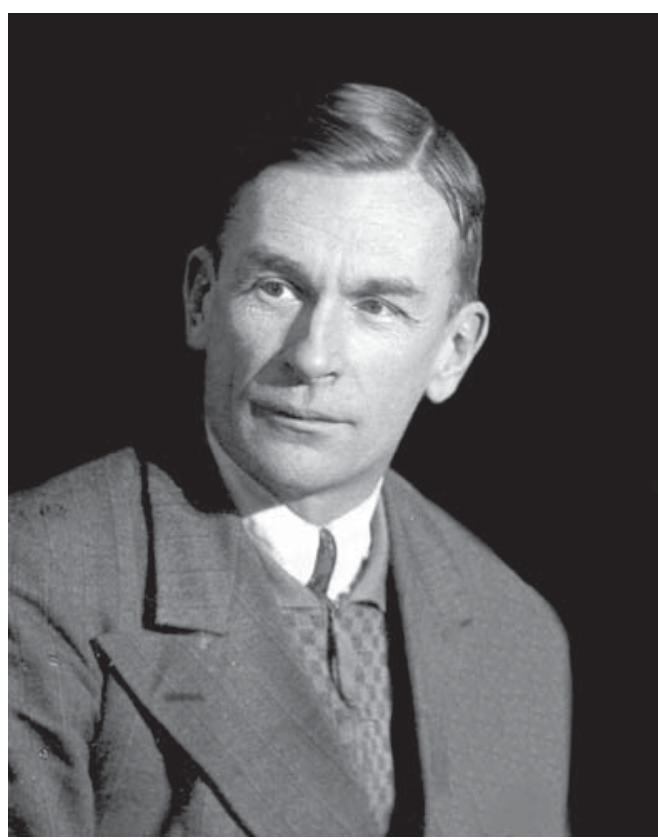

Fig. 15. Associate professor George Abrikosov (1901-1967).

Рис. 15. Доцент Георгий Георгиевич Абрикосов(1901-1967).

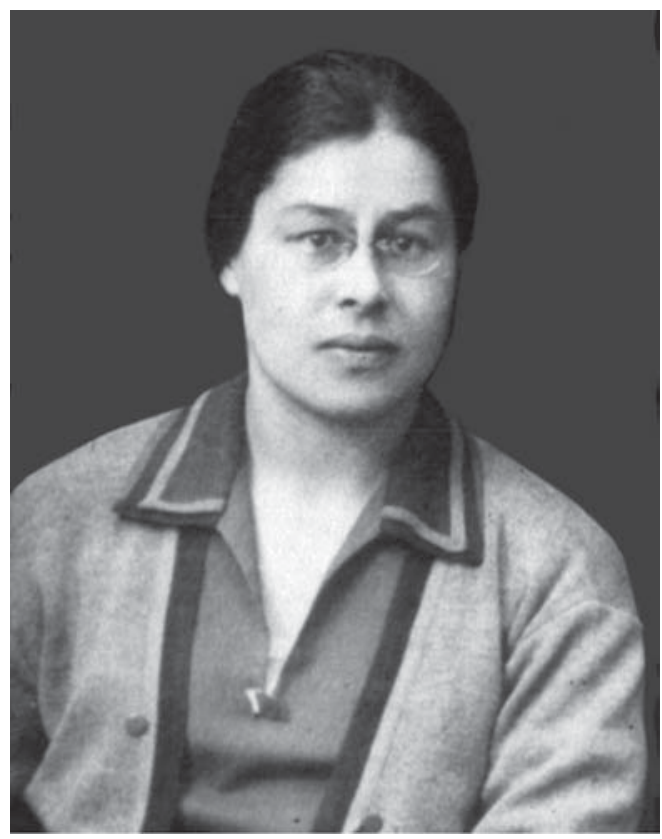

Fig. 16. Associate professor Vera Brotskaya.

Рис. 16. Доцент Вера Александровна Броцкая (1903-1962). 


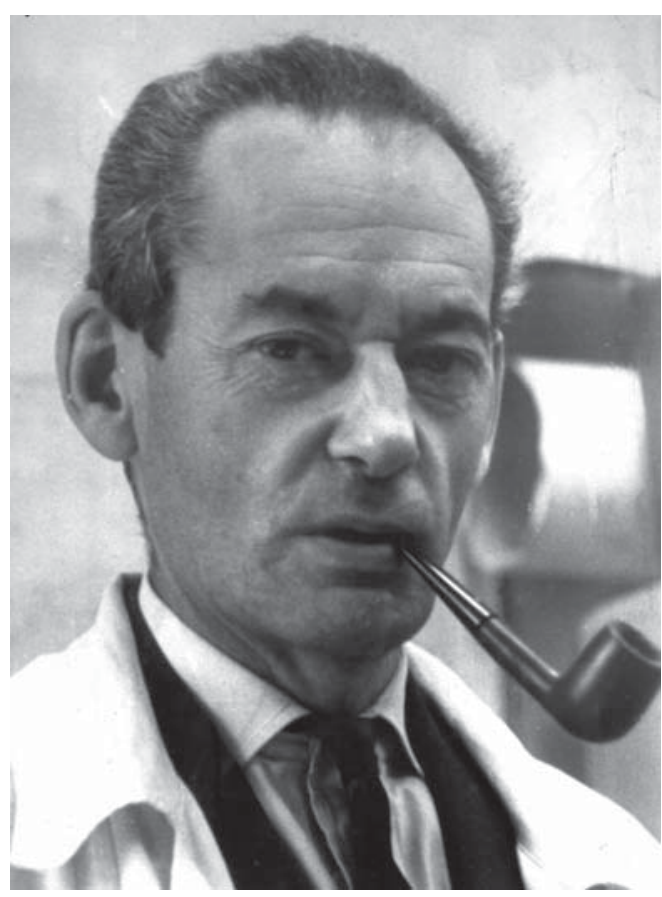

Fig. 17. Professor Yakov Birschtein (1911-1970). Рис. 17. Профессор Яков Авадьевич Бирштейн (1911-1970).

along with three hundred other outstanding scientists signed the so-called "letter of three hundred", which protested against the dictatorship of Trofim Lysenko. The letter was sent to the Central Committee of the Communist Party and helped weaken the position of Lysenko. Lysenko's dictatorship, however, did not collapse until 1964.

Professor Zenkevich had an impressive appearance and autocratic manners. Employees and students of the Department loved and feared him. Behind his back, they called him "Lev" (in Russian it means "the Lion"). Even a few decades after the death of the "Great Lion", his spirit remained in the air of the Department.

Members of the Department and their students studied invertebrates collected by marine expeditions. Professor Yakov Birschtein (Fig. 17) was the most competent expert on isopod crustaceans of the World Ocean and inland waters. He also studied cave fauna. Professor Birschtein was an outstanding lecturer. He was

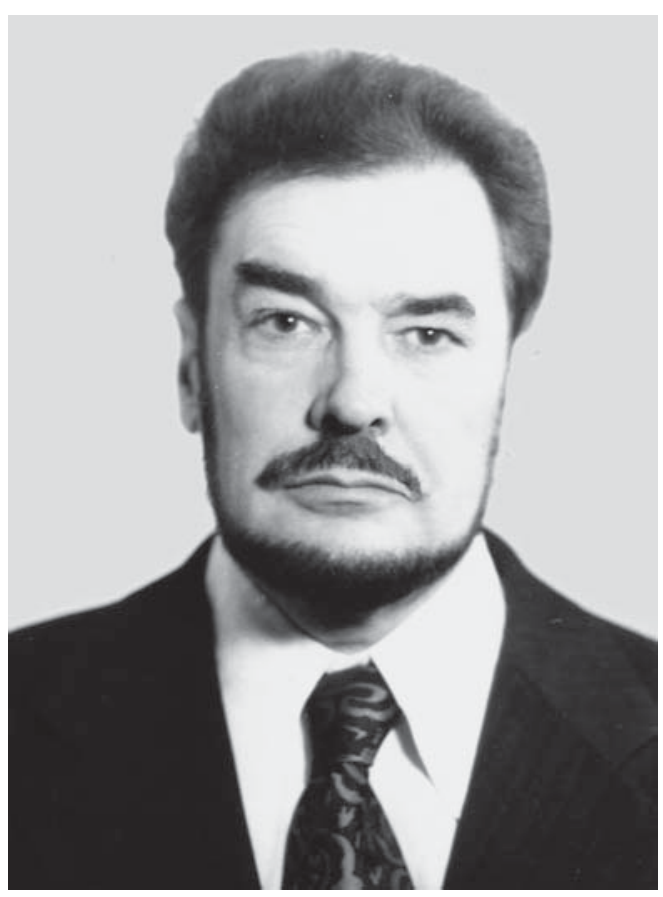

Fig. 18. Professor Vladimir Sveshnikov (1925-1999). Рис. 18. Профессор Владимир Александрович Свешников (1925-1999).

a handsome man with a demonic appearance. During breaks in his lectures, students surrounded him and asked questions, and he answered in a low voice, puffing on a pipe amid clouds of fragrant smoke.

Professor Vladimir Sveshnikov (Fig. 18) studied the morphology and development of polychaetes. Sveshnikov was the son of an artist, and he painted beautifully. He taught students how to depict animals accurately and gracefully. Professor Sveshnikov was a handsome man with elegant manners. He had elegant handwriting and was a refined connoisseur of art.

Dr. Galina Zevina (Fig. 19) was a leading specialist in the study of barnacles. This research was of great practical importance because barnacles contribute to the fouling of ship hulls. She loved students, and many of them became involved in science because of Dr. Zevina's influence.

Professor Zenkevitch died in 1970. The 1970 s and 80 s were years of stagnation in the 


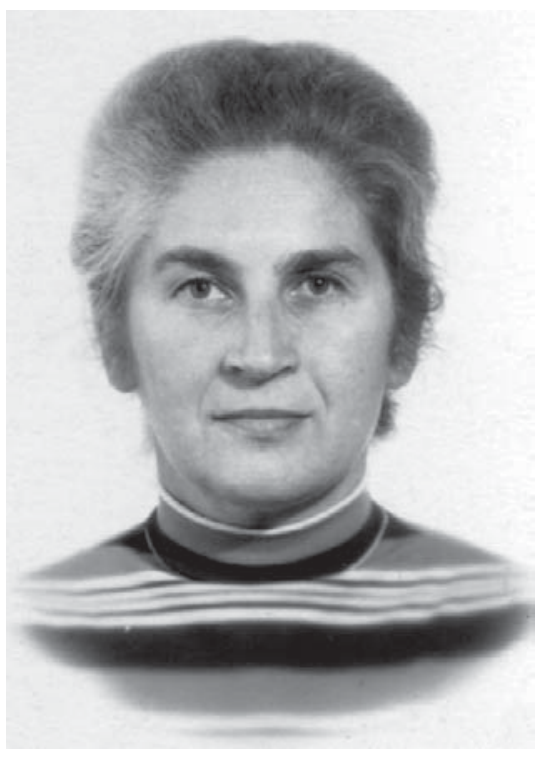

Fig. 19. Dr. Galina Zevina (1926-2002).

Рис. 19. Доктор биологических наук Галина Бенициановна Зевина (1926-2002).

USSR. The Department of Invertebrate Zoology became a victim of intrigues and machinations that poisoned the atmosphere of the Biology Faculty of Moscow University. This is why there was no official head of the Department for 8 years. The Department tried to continue an intensive teaching and scientific research program. Although the acting head of the Department at this time was the veterinarian Dr. Tamara Popova (Fig. 20), the real head of research was Professor Konstantin Beklemishev (Fig. 21). Several marine expeditions were organized under the scientific guidance of Professor Beklemishev. Professor Beklemishev taught the main courses in the Department and had many disciples. Several professors currently active in the Department were the students of Beklemishev (Professor Malakhov, Professor Marfenin, and Professor Tzetlin).

In 1978, the academician Mercury Ghilyarov (Fig. 22) was appointed the head of the Department of Invertebrate Zoology. He headed the Department until his death in 1985. He was a prominent Soviet biologist and the founder of a special branch of biology, Soil Zoology.

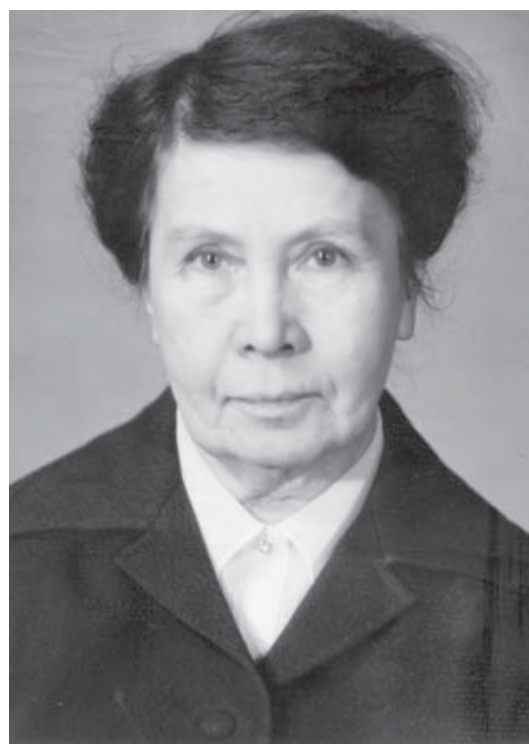

Fig. 20. Professor Tamara Popova (1913-1995).

Рис. 20. Профессор Тамара Игнатьевна Попова (1913-1995).

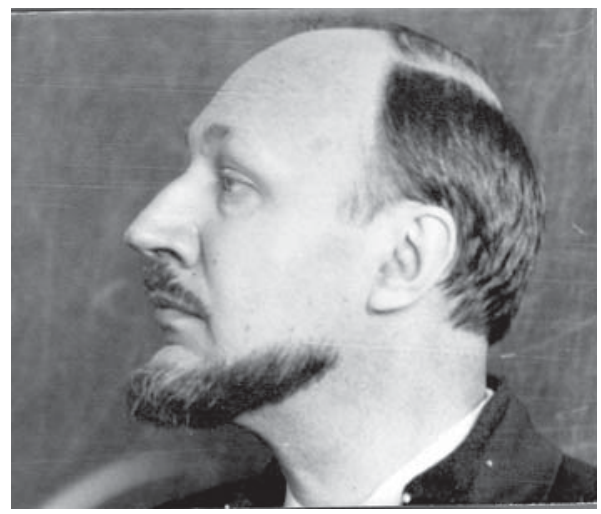

Fig. 21. Professor Konstantin Beklemishev (19281983).

Рис. 21. Профессор Константин Владимирович Беклемишев (1928-1983).

In 1985, Mikhail Gorbachev, who was the General Secretary of the Communist Party of the Soviet Union and also a graduate of Moscow University, initiated the so-called "perestroika". It was a disaster course. In 5 years, Gorbachev led the USSR to its death. The beginning of "perestroika" coincided with a 


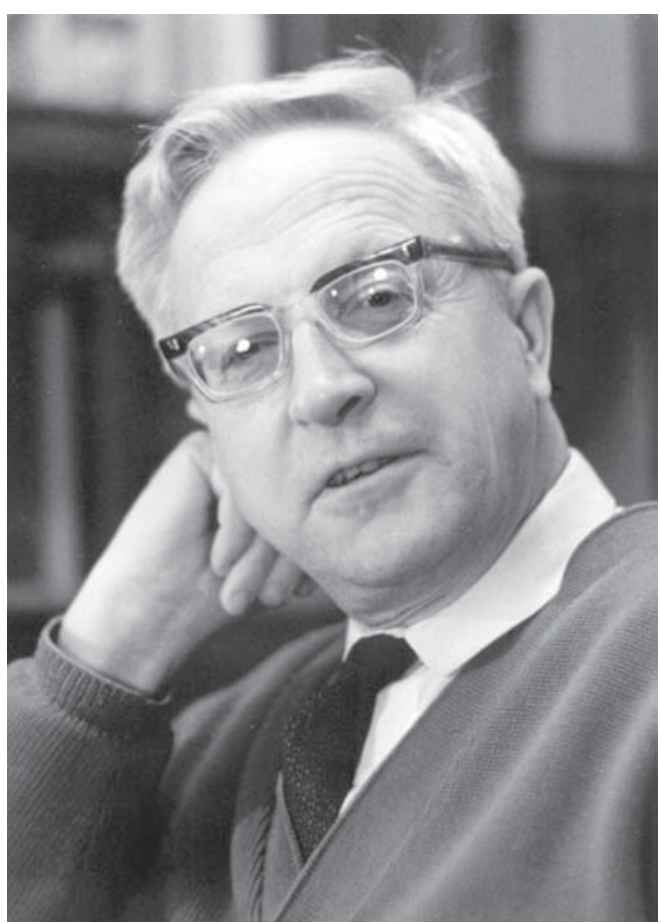

Fig. 22. Professor Mercury Ghilyarov (1912-1985). Рис. 22. Профессор Меркурий Сергеевич Гиляров (1912-1985).

difficult and very conflicted period in the Department. In 1986, Professor Peter Matekin, a malacologist, was appointed the head of the Department of Invertebrate Zoology. At the time of his appointment, Professor Matekin was almost 70 years old. He had participated in the Great Patriotic War, was wounded several times, and was awarded military orders and medals (Fig. 23).

As head of the Department, Professor Matekin faced many obstacles. The 1990s were difficult years for Russian science and education. The leaders of the new Russia ruthlessly destroyed the education system in the country and crippled Russian science. Many thousands of teachers and researchers were forced to leave universities. Thousands of talented scientists went abroad. Russian science and education had never known such a crushing blow. Who was responsible for this? The alcoholic Boris Yeltsin, the brilliantly educated Yegor Gaidar, or the self-confident Anatoly Chubais? Probably only

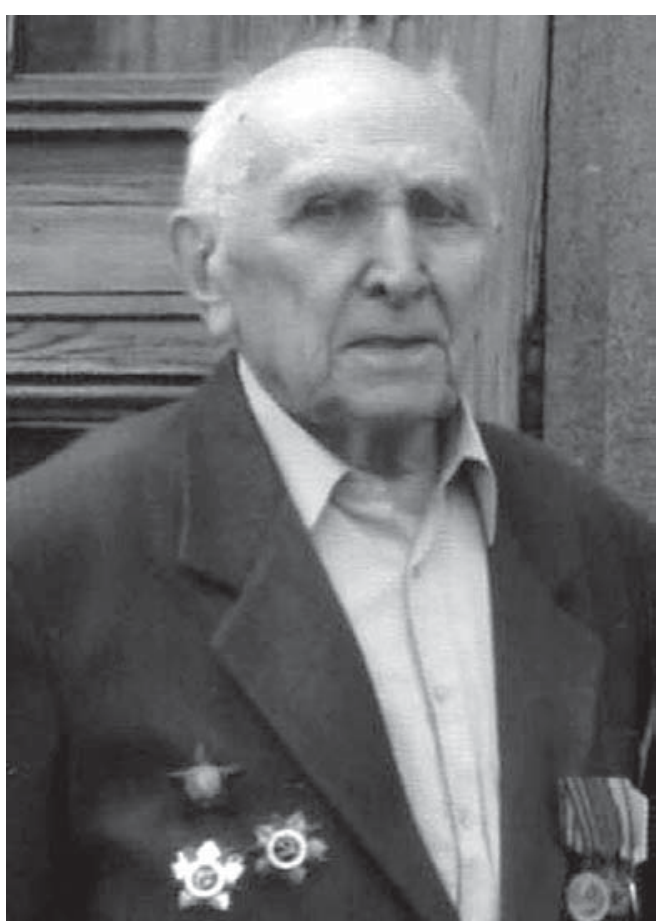

Fig. 23. Professor Peter Matekin (1917-2010).

Рис. 23. Профессор Пётр Владимирович Матёкин (1917-2010).

historians in the distant future will be able to answer this question impartially.

Teachers and researchers in the Department nevertheless preserved the structure of zoological education in the difficult 1990s. In spite of scarce grants and low salaries, the Department staff provided practical courses with the required materials and reagents. Sacrificing their health, the members of Department conducted research and taught practical courses at the White Sea Biological Station in rooms that lacked heating and electrical lighting. At times, it seemed that Russian science would die. The Department, however, was able to survive the 1990s because its employees were committed to research and education.

Professor Matekin headed the Department until 2000, when he was replaced by the corresponding member of the Russian Academy of Sciences, Professor Vladimir Malakhov. At the initiative of Professor Matekin, the Department in 1998 was renamed the "Department of Sys- 
tematics, Comparative Anatomy and Ecology of Invertebrate Animals". The cumbersome name did not catch on, and in 2002 the Department became known as the "Department of Invertebrate Zoology".

This article is devoted to the history of the Department. Historians of the next generation will write about what is happening today. After all, the future always judges the past. Let us give future historians the opportunity to write about today's achievements and failures. At the start of the 21st century, Zoology had undergone a scientific revolution. This revolution was based on new research methods such as molecular biology, confocal and electron microscopy, and computer 3D-modelling. The application of these and other new methods in research and education has become the main everyday task of the Department. The Department currently has four professors (Vladimir Malakhov, Nikolay Marfenin, Alexey Tchesunov, and Alexander Tzetlin). They lecture in the main courses of the
Department. The following scientists in the Department conduct research and teach many practical courses: Polina Belova, Nataly Biserova, Ekaterina Bogomolova, Anastasia Borisanova, Michael Gantsevich, Ilya Gordeev, Ekaterina Egorova, Olga Ezhova, Irina Ekimova, Vyatcheslav Ivanenko, Nadezhda Karaseva, Igor Kosevich, Tatyana Kuzmina, Oleg Malyutin, Alexandra Petrunina, Andrey Prudkovsky, Nadezhda Rimskaya-Korsakova, Galina Salkova, Timur Symdyanov, Artem Sinev, Elena Temereva, Stepan Vodopjanov, Elena Vortsepneva.

The Department resembles a living organism, and people are the particles of this organism. In the words of Professor V.N. Beklemishev, "a living organism has no stable shape, its shape is like a flame formed by a stream of rapidly rushing red-hot particles, particles change, the form remains". People come and go, but the Department lives, as a living flame. Let this flame burn forever!

Responsible editor E.N. Temereva 